\title{
Strategies of active learning methodologies in nursing education: an integrative literature review
}

\author{
Estratégias de metodologias ativas de aprendizagem na formação do enfermeiro: revisão integrativa da literatura
}

Estrategias de metodologías activas de aprendizaje en la formación del enfermero: revisión integrativa de la literatura

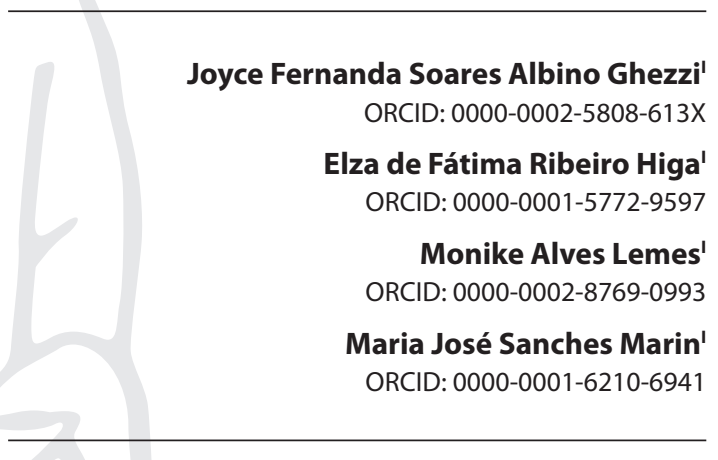

'Faculdade de Medicina de Marília. Marília, São Paulo, Brazil.

How to cite this article:

Ghezzi JFSA, Higa EFR, Lemes MA, Marin MJS. Strategies of active learning methodologies in nursing education: an integrative literature review.

Rev Bras Enferm. 2021;74(1):e20200130. doi: http://dx.doi.org/10.1590/0034-7167-2020-0130

Corresponding author:

Joyce Fernanda Soares Albino Ghezzi

E-mail: jo.albino1988@gmail.com

EDITOR IN CHIEF: Antonio José de Almeida Filho ASSOCIATE EDITOR: Ana Fátima Fernandes

Submission: 04-14-2020

Approval: 08-19-2020

\section{ABSTRACT}

Objectives: to analyze the scientific evidence on the strategies of active learning methodologies used in the training of nurses, as well as their contributions and obstacles in training. Methods: integrative literature review conducted with 33 selected articles in the Medical Literature Analysis and Retrieval System Online, Latin American and Caribbean Literature in Health Sciences, Nursing Database, Scopus, Web of Science and Education Resources Information Center databases. Results: among the strategies, simulation, problem-based learning and flipped classroom were highlighted. The active search, the integration of theory and practice and group work were examples of contributions to the training of nurses. However, the lack of preparation of the actors and the lack of structural support contribute to the dissatisfaction of the students. Final Considerations: the active learning methodology places the student at the heart of the learning process, favors critical thinking and the ability to make decisions. Descriptors: Problem-Based Learning; Education, Nursing; Nurses; Learning; Review.

\section{RESUMO}

Objetivos: analisar as evidências científicas sobre as estratégias de metodologias ativas de aprendizagem utilizadas na formação do enfermeiro, bem como suas contribuições e obstáculos na formação. Métodos: revisão integrativa da literatura realizada com 33 artigos selecionados nas bases de dados Medical Literature Analysis and Retrieval System Online, Literatura LatinoAmericana e do Caribe em Ciências da Saúde, Base de Dados de Enfermagem, Scopus, Web of Science e Education Resources Information Center. Resultados: dentre as estratégias, destacouse a simulação, aprendizagem baseada em problemas e classe invertida. A busca ativa, a integração teoria e prática e o trabalho em grupo foram exemplos de contribuições para a formação do enfermeiro. Todavia, a falta de preparo dos atores e falta de suporte estrutural contribuem para insatisfação dos estudantes. Considerações Finais: a metodologia de aprendizagem ativa coloca o estudante no cerne do processo de aprendizagem, favorece o pensamento crítico e a habilidade de tomar decisões. Descritores: Aprendizagem Baseada em Problemas; Educação em Enfermagem; Enfermeiro; Aprendizagem; Revisão.

\section{RESUMEN}

Objetivos: analizar evidencias científicas sobre las estrategias de metodologías activas de aprendizaje utilizadas en la formación del enfermero, así como sus contribuciones y obstáculos. Métodos: revisión integrativa de la literatura realizada con 33 artículos seleccionados en las bases de datos Medical Literature Analysis and Retrieval System Online, Literatura Latinoamericana y del Caribe en Ciencias de la Salud, Base de Datos de Enfermería, Scopus, Web of Science y Education Resources Information Center. Resultados: entre las estrategias, se destacaron la simulación, aprendizaje basada en problemas y clase invertida. La búsqueda activa, la integración teoría y práctica y el trabajo en equipo fueron ejemplos de contribuciones para la formación del enfermero. Aunque, la falta de preparo y de suporte estructural contribuyen para insatisfacción de los estudiantes. Consideraciones Finales: la metodología de aprendizaje activa coloca el estudiante en el núcleo del proceso de aprendizaje, favorece el pensamiento crítico y la habilidad de tomar decisiones.

Descriptores: Aprendizaje Basada en Problemas; Educación en Enfermería; Enfermero; Aprendizaje; Revisión. 


\section{INTRODUCTION}

With the growing technological and scientific advance of the last decades, the training of nurses has been configured as a complex and challenging process, requiring skills of critical, logical and questioning reasoning ${ }^{(1)}$. In this regard, in order for social demands to be met, professionals are required to work with Evidence-Based Practices (EBP), with prudent, responsible and committed decision making, abstaining from empirical knowledge.

In view of these assumptions, the National Curricular Guidelines (NCGs) for Nursing courses state that professionals should be able to think critically, based on principles of ethics/bioethics(2). However, the actors involved in the formation of the nurse still find it difficult to achieve a formation within a model adverse to the hegemonic, which is contentist of technical conception, as well as to transpose the paradigms that sustain it ${ }^{(3)}$.

In order to advance in the formation of a professional with a profile that is close to the NCGs, the active methodologies of learning have been gaining space, because they propose to bring the student to the center of the teaching and learning process, through experiences of real situations, embracing significant knowledge. This process unbinds the student from a methodology that robotizes him/her by limiting him/her to only what is transmitted to him/her, breaking the paradigm of teaching for true learning ${ }^{(4)}$.

A study carried out in Chile reaffirms the benefits brought by active student learning methodologies and adds that this movement originated from the assumptions of educational philosophers such as Jean-Jacques Rousseau and John Dewey and pedagogues such as Johann Heinrich Pestalozzi and Friedrich Froebel, who, since 1900, have invested in and encouraged a student-centered education ${ }^{(5)}$.

The active learning methodologies, besides breaking traditionalism with new perspectives of teaching and learning, provide a range of content that perhaps would not be explored in the traditional method, or, if explored, would not have so much meaning to the student. In active learning methodologies, the greater the student's involvement in the content discussed, the greater their ability to understand. Moreover, the correlation between abstract knowledge and its application to the real world promotes the interaction between theory and practice and, by actively participating in the learning process, the student acquires a greater capacity to memorize, since the brain acts in a more dynamic way. It is added that the trajectory of active learning must be guided by a final objective to be achieved, so that the student knows where he or she needs to get to ${ }^{(6)}$.

A survey conducted at a federal university in southern Brazil indicated that active learning methodologies provide subsidies for the training of critical and reflective nurses, leading students to situations that require discussions and arguments of content based on a given context ${ }^{(3)}$. Nowadays, faced with the need to adopt an active learning methodology, different strategies are used, which need to be highlighted in order to contribute to the formation of the nurse.

Thus, it can be seen that although active learning methodologies are being used in vocational training, many are their forms of use. Therefore, this research starts from the following question: What are the strategies of active learning methodologies used in the training of nurses and what are their contributions and obstacles to the learning process?

\section{OBJECTIVES}

To analyze the scientific evidence on the strategies of active learning methodologies used in the training of nurses, as well as their contributions and obstacles in training.

\section{METHODS}

This is an Integrative Literature Review (ILR) study, which is considered an instrument of EBP and is characterized by an approach to clinical care and teaching based on knowledge and quality of evidence. It involves defining the problem, identifying the necessary information, conducting the search for studies in the literature and their critical evaluation, identifying the applicability of data from publications and determining their use for the patient ${ }^{(7)}$.

ILR comprises six interlinked stages: The first one deals with the guiding question, being the most important phase of the review, since it determines the terms to be used in the search for bibliographic material, as well as the inclusion and exclusion criteria.

Following the criteria of the acronym PICo ( $\mathrm{P}=$ Population, $\mathrm{I}=$ Intervention, $\mathrm{Co}=$ Context), the guiding question of this research was structured as follows: P: Nursing undergraduate courses; I: strategies of active learning methodologies; Co: nurse training ${ }^{(8)}$. We then started from the following question: Which are the strategies of active learning methodologies used in the training of nurses and which are their contributions and obstacles to the learning process? For the second stage, which deals with database searching, the use of controlled and uncontrolled descriptors linked to Boolean operators (AND; OR) was established, applied in the following databases: Medical Literature Analysis and Retrieval System Online (MEDLINE), with access through PubMed, Latin American and Caribbean Literature in Health Sciences (LILACS), Nursing Database (BDENF), Scopus, Web Of Science (WOS) and Education Resources Information Center (Eric).

The searches were carried out from October to November 2018, in a time slot from 2015 to 2018, in order to obtain data from the most recent literature in Portuguese, English and Spanish. Initially, a total of 731 references were obtained, which, after being exported to the Endnote reference manager and excluding the repetitions, totaled 660 references. Books, theses, dissertations, literature review articles and those that did not deal with the nursing graduate were excluded. After reading the titles, 260 abstracts were selected; in the sequence, 134 articles were read in full and, finally, 33 articles were analyzed, as shown in Chart 1 .

After the selection of the articles, the third stage of the study was carried out, which consists of extracting the data from the selected articles. For this purpose, a script was used, including the journal in which it was published, the year and country of the research, the title, the authors, the objective, the method, the sample definition, the teaching strategy adopted in the study, the main results and relevant observations. 
Chart 1 - Database search path

\begin{tabular}{|c|c|c|c|c|c|c|}
\hline Database & Keywords & $\begin{array}{l}\text { Total of } \\
\text { references }\end{array}$ & $\begin{array}{l}\text { Total after discarding of } \\
\text { duplicity by Endnote }\end{array}$ & $\begin{array}{l}\text { Analyzed } \\
\text { abstracts }\end{array}$ & $\begin{array}{l}\text { References for } \\
\text { reading in full }\end{array}$ & $\begin{array}{c}\text { References for } \\
\text { Integrative Review }\end{array}$ \\
\hline MEDLINE & $\begin{array}{l}\text { (active learning) and ((nurse } \\
\text { training) or (teaching nurse) }\end{array}$ & 544 & 543 & 151 & 81 & 13 \\
\hline $\begin{array}{l}\text { LILACS } \\
+ \text { +BDENF }\end{array}$ & $\begin{array}{l}\text { (active learning) or (active } \\
\text { learning)) and ((training or } \\
\text { teaching) and nurse)) }\end{array}$ & 5 & 4 & 3 & 3 & 2 \\
\hline Scopus & $\begin{array}{l}\text { (active learning) and ((nurse } \\
\text { training) or (teaching nurse) }\end{array}$ & 37 & 34 & 34 & 15 & 1 \\
\hline wOS & $\begin{array}{l}\text { (active learning) and ((nurse } \\
\text { training) or (teaching nurse) }\end{array}$ & 136 & 70 & 66 & 34 & 17 \\
\hline Eric & $\begin{array}{l}\text { (active learning) and ((nurse } \\
\text { training) or (teaching nurse) }\end{array}$ & 9 & 9 & 6 & 1 & 0 \\
\hline \multicolumn{2}{|l|}{ TOTAL } & 731 & 660 & 260 & 134 & 33 \\
\hline
\end{tabular}

In the fourth stage, a critical analysis of the studies included was performed, focusing on the strategies of active learning methodologies implemented in the training of nurses and in which were the main results, considering the potential and obstacles.

In the fifth stage, the findings were discussed, through the interpretation and synthesis of the results, in articulation with the theoretical framework, in the identification of possible gaps in knowledge and in the delimitation of priorities for future studies.

In addition, the articles were submitted to the Oxford Centre Evidence-Based Medicine criteria, which ranks them between levels 1 and 5, with level 1 being the most evident and, consequently, level 5 the least evident $t^{(9)}$. Finally, the sixth step is followed by the presentation of the review with pertinent and detailed information.

\section{RESULTS}

The analysis of the 33 selected articles described in Chart 2 shows that the United States of America was the country with the largest number of studies, followed by Brazil and Iran. There was a concentration of publications in 2015 and 2017, with 20 articles. The journals with the most publications were Nursing Education on Today, with eight, followed by Nursing Educations in Pratice, with five publications. Regarding the methodological approach, the predominance of qualitative research of the descriptive type is observed, present in 13 articles, as well as experience reports, in nine articles. According to the methodological approaches, the prevailing level of evidence was $4^{(9)}$.

Among the active learning strategies cited in the articles, simulation (nine articles), followed by Problem Based Learning (PBL) (six), and the others cited the flipped classroom, virtual strategies, among others, and some studies present more than one approach.

In the analysis of the contributions that the use of active learning methodologies provide for the training of nurses, the following is highlighted: the active search for knowledge, which places the student as an active agent of knowledge itself, making it the center of the teaching-learning process, resulting in significant learning; the integration of theory with practice, which favors the self-confidence of the student, making him/her more prepared for the job market, more empathic, safe and creative; the preparation for group work, because it develops the capacity of communication, the evaluation of his/her own learning, as well as the learning of the group, leading to the awareness of his/her limitations and needs, which enables the reconstruction of the phenomenon studied. In addition, the development of critical thinking is pointed as a contribution of the active learning methodologies, making the student reflect on the content learned and acquire skills for decision-making.

Chart 2 - Distribution of articles according to title, reference, year of publication, country, delineation/number of students, strategies and main results, Marília, São Paulo, Brazil, 2019

\begin{tabular}{|l|c|c|l|l|}
\hline Title and Reference & $\begin{array}{c}\text { Year } \\
\text { Country }\end{array}$ & $\begin{array}{c}\text { Design/ } \\
\text { Number of } \\
\text { students }\end{array}$ & Strategies & Main results \\
\hline $\begin{array}{l}\text { Flipping the Classroom Strategies for } \\
\text { Psychiatric-Mental Health Course }\end{array}$ & $\begin{array}{c}2015 \\
\text { UNITED STATES } \\
\text { OF AMERICA }\end{array}$ & $\begin{array}{c}\text { Experience report } \\
\mathrm{n}=359\end{array}$ & Flipped classroom & $\begin{array}{l}\text { The students realized that they were well } \\
\text { prepared for active involvement in the classroom }\end{array}$ \\
\hline $\begin{array}{l}\text { The benefits of active learning: Applying } \\
\text { Brunner's discovery theory to the } \\
\text { classroom: Teaching clinical decision- } \\
\text { making to senior nursing students }\end{array}$ & $\begin{array}{c}\text { UN1) } \\
\text { UNITE STATES } \\
\text { OF AMERICA }\end{array}$ & $\begin{array}{c}\text { Experience report } \\
\mathrm{n}=\text { not specified }\end{array}$ & Flipped classroom & $\begin{array}{l}\text { Students felt more prepared to think critically, } \\
\text { not just to memorize }\end{array}$ \\
\hline $\begin{array}{l}\text { Enhancing Student Engagement: } \\
\text { Innovative Strategies for Intentional } \\
\text { Learning }\end{array}$ & $\begin{array}{c}\text { 2018 } \\
\text { UNITED STATES } \\
\text { OF AMERICA }\end{array}$ & $\begin{array}{c}\text { Descriptive study } \\
\mathrm{n}=\text { not specified }\end{array}$ & Simulation & $\begin{array}{l}\text { Nursing students had better engagement scores } \\
\text { measured by active and collaborative learning. }\end{array}$ \\
\hline
\end{tabular}




\begin{tabular}{|c|c|c|c|c|}
\hline Title and Reference & $\begin{array}{l}\text { Year } \\
\text { Country }\end{array}$ & $\begin{array}{l}\text { Design/ } \\
\text { Number of } \\
\text { students }\end{array}$ & Strategies & Main results \\
\hline $\begin{array}{l}\text { The Living Family Tree: Bridging } \\
\text { the Gap Between Knowledge and } \\
\text { Practice in a Family Nurse Practitioner } \\
\text { Program }\end{array}$ & $\begin{array}{l}2015 \\
\text { UNITED STATES } \\
\text { OF AMERICA }\end{array}$ & $\begin{array}{l}\text { Descriptive study } \\
\qquad n=266\end{array}$ & $\begin{array}{l}\text { Problem Based } \\
\text { Learning: Living } \\
\text { family tree }\end{array}$ & $\begin{array}{l}\text { Students improved clinical reasoning and } \\
\text { problem-solving skills, ease of clinical practice, } \\
\text { greater control and autonomy in their learning } \\
\text { process. }\end{array}$ \\
\hline $\begin{array}{l}\text { The use of a game-based learning } \\
\text { platform to engage nursing students: } \\
\text { A descriptive, qualitative study }{ }^{(14)}\end{array}$ & $\begin{array}{l}2017 \\
\text { UNITED STATES } \\
\text { OF AMERICA }\end{array}$ & $\begin{array}{l}\text { Descriptive study } \\
\quad \mathrm{n}=57\end{array}$ & Virtual strategies & $\begin{array}{l}\text { The time to learn how to use the platform } \\
\text { was limited. The implementation of the } \\
\text { strategy could have been better received if } \\
\text { an information technologist had provided } \\
\text { guidance and assistance in solving problems. }\end{array}$ \\
\hline $\begin{array}{l}\text { Critical thinking cards: An innovative } \\
\text { teaching strategy to bridge classroom } \\
\text { knowledge with clinical decision } \\
\text { making }^{(15)}\end{array}$ & $\begin{array}{l}2016 \\
\text { UNITED STATES } \\
\text { OF AMERICA }\end{array}$ & $\begin{array}{l}\text { Experience report } \\
\qquad \mathrm{n}=66\end{array}$ & $\begin{array}{l}\text { Critical Thinking } \\
\quad \text { Cards }\end{array}$ & $\begin{array}{l}\text { It helped students apply the content and } \\
\text { improved clinical judgment. Students } \\
\text { demonstrated a desire for more questions to } \\
\text { improve critical thinking and reasoning, as } \\
\text { well as the application of this activity in other } \\
\text { disciplines. }\end{array}$ \\
\hline $\begin{array}{l}\text { Implementing Collaborative Learning } \\
\text { in Prelicensure Nursing Curricula } \\
\text { Student Perceptions and Learning } \\
\text { Outcomes }{ }^{(16)}\end{array}$ & $\begin{array}{l}2015 \\
\text { UNITED STATES } \\
\text { OF AMERICA }\end{array}$ & $\begin{array}{l}\text { Action Research } \\
\quad \mathrm{n}=346\end{array}$ & $\begin{array}{l}\text { Cooperative } \\
\text { Learning }\end{array}$ & $\begin{array}{l}\text { The activity contributes to the understanding } \\
\text { of the content, responsibility with the } \\
\text { self-preparation for classroom. There were } \\
\text { difficulties to work in group and to know if the } \\
\text { content was being understood in the right way, } \\
\text { which generated anguish. }\end{array}$ \\
\hline $\begin{array}{l}\text { Back to the Basics and Beyond: } \\
\text { Comparing Traditional and Innovative } \\
\text { Strategies for Teaching in Nursing } \\
\text { Skills Laboratories }^{(17)}\end{array}$ & $\begin{array}{l}2016 \\
\text { UNITED STATES } \\
\text { OF AMERICA }\end{array}$ & $\begin{array}{l}\text { Mixed study } \\
\quad \mathrm{n}=39\end{array}$ & Simulation & $\begin{array}{l}\text { Instructor demonstrations and the impact } \\
\text { on learning and confidence were considered } \\
\text { important. }\end{array}$ \\
\hline $\begin{array}{l}\text { Can nursing students' confidence } \\
\text { levels increase with repeated } \\
\text { simulation activities? }\end{array}$ & $\begin{array}{l}2015 \\
\text { UNITED STATES } \\
\text { OF AMERICA }\end{array}$ & $\begin{array}{l}\text { Experience report } \\
\qquad \mathrm{n}=54\end{array}$ & Simulation & $\begin{array}{l}\text { The simulations promote critical thinking, } \\
\text { active learning in a real world environment, } \\
\text { group coexistence and reflection on their } \\
\text { performance. }\end{array}$ \\
\hline $\begin{array}{l}\text { Large Group Simulation: Using } \\
\text { Combined Teaching Strategies to } \\
\text { Connect Classroom and Clinical } \\
\text { Learning } 1^{(19)}\end{array}$ & $\begin{array}{l}2015 \\
\text { UNITED STATES } \\
\text { OF AMERICA }\end{array}$ & $\begin{array}{l}\text { Experience report } \\
\qquad \mathrm{n}=46\end{array}$ & Simulation & $\begin{array}{l}\text { The students evaluated the experience } \\
\text { positively, for having more confidence in their } \\
\text { skills and starting to think more critically. }\end{array}$ \\
\hline $\begin{array}{l}\text { Comparing the effects of traditional } \\
\text { lecture e and flipped classroom on } \\
\text { nursing STUDENTS' critical thinking } \\
\text { disposition: A quasi-experimental } \\
\text { study }{ }^{(20)}\end{array}$ & $\begin{array}{l}2018 \\
\text { IRAN }\end{array}$ & $\begin{array}{c}\text { Quasi } \\
\text { experimental study } \\
n=85\end{array}$ & Flipped classroom & Facilitates memorization. \\
\hline $\begin{array}{l}\text { The effect of blended training } \\
\text { (Programmed and Lecture-Based } \\
\text { Training) on learning health status } \\
\text { assessment course among nursing } \\
\text { students }^{(21)}\end{array}$ & $\begin{array}{l}2017 \\
\text { IRAN }\end{array}$ & $\begin{array}{l}\text { Quasi } \\
\text { experimental study } \\
n=60\end{array}$ & Virtual strategies & $\begin{array}{l}\text { The average course scores were higher than } \\
\text { those of the control group. }\end{array}$ \\
\hline $\begin{array}{l}\text { Comparing the effects of problem- } \\
\text { based learning and the traditional } \\
\text { lecture method on critical thinking } \\
\text { skills and metacognitive awareness } \\
\text { in nursing students in a critical care } \\
\text { nursing course }{ }^{(22)}\end{array}$ & $\begin{array}{l}2016 \\
\text { IRAN }\end{array}$ & $\begin{array}{l}\text { Quasi } \\
\text { experimental study } \\
n=40\end{array}$ & $\begin{array}{l}\text { Problem Based } \\
\quad \text { Learning }\end{array}$ & $\begin{array}{l}\text { Increases students' critical skills and acceptance } \\
\text { of divergent views. }\end{array}$ \\
\hline $\begin{array}{l}\text { A comparison of educational } \\
\text { strategies for the acquisition of } \\
\text { nursing student's performance and } \\
\text { critical thinking: simulation-based } \\
\text { training vs. integrated training } \\
\text { (simulation and critical thinking }_{\text {strategies)(23) }}\end{array}$ & $\begin{array}{l}2016 \\
\text { IRAN }\end{array}$ & $\begin{array}{l}\text { Quasi } \\
\text { experimental study } \\
n=40\end{array}$ & Simulation & $\begin{array}{l}\text { The experimental group obtained a higher } \\
\text { performance score, however this training } \\
\text { method did not fully strengthen the students' } \\
\text { capacity for critical thinking, according to all } \\
\text { the cognitive requirements of critical thinking. }\end{array}$ \\
\hline $\begin{array}{l}\text { Teaching and learning strategies in } \\
\text { hospital nursing internship of an } \\
\text { integrated curriculum }\end{array}$ & $\begin{array}{c}2017 \\
\text { BRAZIL }\end{array}$ & $\begin{array}{l}\text { Descriptive study } \\
\qquad \mathrm{n}=18\end{array}$ & $\begin{array}{c}\text { Group discussion; } \\
\text { Problem-situation; } \\
\text { Spoken newspaper; } \\
\text { Portfolio; Group } \\
\text { dynamics; } \\
\text { Exhibition-dialogue; } \\
\text { Movies/videos }\end{array}$ & $\begin{array}{l}\text { More critical, reflective learning. As weaknesses, } \\
\text { the individual overload in group work; } \\
\text { difficulties in educating students; coercive } \\
\text { teaching posture; dynamics outside the } \\
\text { theoretical context; films not didactic, outdated } \\
\text { and out of the reality experienced. }\end{array}$ \\
\hline
\end{tabular}


Chart 2

\begin{tabular}{|c|c|c|c|c|}
\hline Title and Reference & $\begin{array}{l}\text { Year } \\
\text { Country }\end{array}$ & $\begin{array}{l}\text { Design/ } \\
\text { Number of } \\
\text { students }\end{array}$ & Strategies & Main results \\
\hline $\begin{array}{l}\text { Perception of undergraduate nursing } \\
\text { students on realistic simulation }{ }^{(25)}\end{array}$ & $\begin{array}{l}2017 \\
\text { BRAZIL }\end{array}$ & $\begin{array}{l}\text { Descriptive study } \\
\qquad \mathrm{n}=37\end{array}$ & Simulation & $\begin{array}{l}\text { Approach with various contexts of practice. } \\
\text { Previous experience is reverted into knowledge } \\
\text { and generates security. Simulation both } \\
\text { enhances the practice of clinical skills and } \\
\text { allows for critical thinking and analysis of the } \\
\text { various practical situations. }\end{array}$ \\
\hline $\begin{array}{l}\text { Active teaching methodology in nurse } \\
\text { training: innovation in basic care }{ }^{(26)}\end{array}$ & $\begin{array}{l}2015 \\
\text { BRAZIL }\end{array}$ & $\begin{array}{l}\text { Experience report } \\
\qquad \mathrm{n}=8\end{array}$ & Problematization & $\begin{array}{l}\text { Encourages interest and initiative for the } \\
\text { integration of knowledge, favouring the } \\
\text { teaching-learning process. }\end{array}$ \\
\hline $\begin{array}{l}\text { Active methodologies in nursing } \\
\text { graduation: a focus on care for the } \\
\text { elderly } 2 \text { (27) }\end{array}$ & $\begin{array}{l}2017 \\
\text { BRAZIL }\end{array}$ & $\begin{array}{l}\text { Experience report } \\
\qquad \mathrm{n}=10\end{array}$ & Simulation & $\begin{array}{l}\text { It articulates theoretical and practical } \\
\text { knowledge, provides experiences similar } \\
\text { to situations observed in reality and } \\
\text { develops skills related to problem solving, } \\
\text { communication, decision making. }\end{array}$ \\
\hline $\begin{array}{l}\text { Quasi-experimental study on the } \\
\text { effectiveness of a flipped classroom } \\
\text { for teaching adult health nursing }\end{array}$ & $\begin{array}{l}2017 \\
\text { SOUTH KOREA }\end{array}$ & $\begin{array}{l}\text { Quasi } \\
\text { experimental study } \\
n=81\end{array}$ & Flipped classrom & $\begin{array}{l}\text { Improvement in critical thinking, creativity, } \\
\text { cognitive skills and academic performance. }\end{array}$ \\
\hline $\begin{array}{l}\text { Comparison of knowledge, confidence } \\
\text { in skill performance (CSP) and } \\
\text { satisfaction in problem-based learning } \\
\text { (PBL) and simulation with PBL } \\
\text { educational modalities in caring for } \\
\text { children with bronchiolitis }{ }^{(29)}\end{array}$ & \begin{tabular}{c|}
2015 \\
SOUTH KOREA
\end{tabular} & $\begin{array}{l}\text { Descriptive study } \\
\qquad n=205\end{array}$ & $\begin{array}{l}\text { Problem Based } \\
\text { Learning and } \\
\text { Problematization }\end{array}$ & $\begin{array}{l}\text { The Problem Based Learning group and the } \\
\text { combination of simulation results combined } \\
\text { obtained higher confidence and knowledge } \\
\text { scores than the traditional learning methods } \\
\text { group. Students suggest that the Problem } \\
\text { Based Learning and a blended learning method } \\
\text { are more effective in improving knowledge, } \\
\text { confidence and satisfaction. In simulation } \\
\text { alone, students did not feel so confident. }\end{array}$ \\
\hline $\begin{array}{l}\text { Concept mapping to promote } \\
\text { meaningful learning, help relate } \\
\text { theory to practice and improve } \\
\text { learning self-efficacy in Asian mental } \\
\text { health nursing students: A mixed- } \\
\text { methods pilot study }{ }^{(30)}\end{array}$ & $\begin{array}{l}2018 \\
\text { CHINA }\end{array}$ & $\begin{array}{l}\text { Mixed study } \\
\qquad \mathrm{n}=70\end{array}$ & $\begin{array}{l}\text { Conceptual } \\
\text { Mapping }\end{array}$ & $\begin{array}{l}\text { The conceptual mapping approach can be } \\
\text { useful for assessing your learning, promoting } \\
\text { reflective learning, and encouraging the } \\
\text { integration of theoretical knowledge with } \\
\text { clinical knowledge, to a deeper level of } \\
\text { understanding. }\end{array}$ \\
\hline $\begin{array}{l}\text { Student peer reviewers' views on } \\
\text { teaching innovations and imaginative } \\
\text { learning } \\
\text { (31) }\end{array}$ & $\begin{array}{l}2016 \\
\text { CHINA }\end{array}$ & $\begin{array}{l}\text { Experience report } \\
\qquad \mathrm{n}=18\end{array}$ & $\begin{array}{l}\text { Imaginative } \\
\text { learning with } \\
\text { poetry, songs and } \\
\text { role-plays }\end{array}$ & $\begin{array}{l}\text { LFT provides better conditions for } \\
\text { learning, critical thinking, decision-making } \\
\text { and communication skills; and if this } \\
\text { methodological strategy is joined with other } \\
\text { activities, learning becomes even more } \\
\text { significant. }\end{array}$ \\
\hline $\begin{array}{l}\text { Students take the lead for learning in } \\
\text { practice: A process for building self- } \\
\text { efficacy into undergraduate nursing } \\
\text { education }^{(32)}\end{array}$ & $\begin{array}{l}2018 \\
\text { AUSTRALIA }\end{array}$ & $\begin{array}{l}\text { Descriptive study } \\
\qquad n=431\end{array}$ & $\begin{array}{l}\text { Check-in e Check- } \\
\text { out }\end{array}$ & $\begin{array}{l}\text { The Check-in e Check-out process can be an } \\
\text { effective tool for active engagement and } \\
\text { learning in clinical learning spaces. It promotes } \\
\text { learner empowerment and engagement in } \\
\text { their own learning experiences. }\end{array}$ \\
\hline $\begin{array}{l}\text { CaseWorld: Interactive, media } \\
\text { rich, multidisciplinary case based } \\
\text { learning }\end{array}$ & $\begin{array}{l}2015 \\
\text { AUSTRALIA }\end{array}$ & $\begin{array}{l}\text { Descriptive study } \\
\qquad n=197\end{array}$ & Case study & $\begin{array}{l}\text { The case study benefits learning. Real-life } \\
\text { scenarios give a holistic view of learning. }\end{array}$ \\
\hline $\begin{array}{l}\text { Using technology to enhance nurse } \\
\text { practitioner student engagement }{ }^{(34)}\end{array}$ & $\begin{array}{c}2015 \\
\text { No information }\end{array}$ & $\begin{array}{l}\text { Experience report } \\
\mathrm{n}=\text { not specified }\end{array}$ & Simulation & $\begin{array}{l}\text { Simulation-based learning offers the } \\
\text { opportunity for experiential learning in a safe } \\
\text { and risk-free environment. }\end{array}$ \\
\hline $\begin{array}{l}\text { The Learning Preferences among } \\
\text { Nursing Students in the King Saud } \\
\text { University in Saudi Arabia: A Cross- } \\
\text { Sectional Survey }\end{array}$ & $\begin{array}{l}2017 \\
\text { SAUDI ARABIA }\end{array}$ & $\begin{array}{l}\text { Descriptive study } \\
\qquad \mathrm{n}=56\end{array}$ & $\begin{array}{l}\text { Visual strategies; } \\
\text { active method; } \\
\text { sequential and } \\
\text { verbal }\end{array}$ & $\begin{array}{l}\text { According to their preferences, students chose } \\
\text { visual style }(67.9 \%) \text { as their teaching strategy, } \\
\text { followed by the active }(50 \%) \text { and sequential } \\
(37.5 \%) \text { method. The verbal style was the least } \\
\text { chosen }(3.6 \%) \text {. }\end{array}$ \\
\hline $\begin{array}{l}\text { Clinical education Improvement of } \\
\text { learning domains of nursing students } \\
\text { with the use of authentic assessment } \\
\text { pedagogy in clinical practice }{ }^{(36)}\end{array}$ & $\begin{array}{l}2016 \\
\text { SINGA } \\
\text { PURE }\end{array}$ & $\begin{array}{l}\text { Quasi } \\
\text { experimental study } \\
n=54\end{array}$ & $\begin{array}{l}\text { Pedagogy } \\
\text { of authentic } \\
\text { evaluation }\end{array}$ & $\begin{array}{l}\text { It helped to improve the domains of learning } \\
\text { and critical thinking skills. Allows a closer } \\
\text { sequencing of theory and practice, so that } \\
\text { students better understand their ability and } \\
\text { safety. }\end{array}$ \\
\hline $\begin{array}{l}\text { Influence of Co-teaching on } \\
\text { Undergraduate Student Learning: A } \\
\text { Mixed-Methods Study in Nursing }\end{array}$ & $\begin{array}{l}2018 \\
\text { CANADA }\end{array}$ & $\begin{array}{l}\text { Mixed study } \\
\quad \mathrm{n}=65\end{array}$ & $\begin{array}{l}\text { Cooperative } \\
\text { Learning }\end{array}$ & $\begin{array}{l}\text { Develops self-confidence to work collaboratively } \\
\text { within interprofessional teams and to support } \\
\text { patient-centered care. The ability to question } \\
\text { and reflect on one's own learning is a key } \\
\text { element to being a successful learner. }\end{array}$ \\
\hline
\end{tabular}




\begin{tabular}{|c|c|c|c|c|}
\hline Title and Reference & $\begin{array}{l}\text { Year } \\
\text { Country }\end{array}$ & $\begin{array}{l}\text { Design/ } \\
\text { Number of } \\
\text { students }\end{array}$ & Strategies & Main results \\
\hline $\begin{array}{l}\text { Practice and effectiveness of web- } \\
\text { based problem-based learning } \\
\text { approach in a large class-size system: } \\
\text { A comparative study }^{(38)}\end{array}$ & $\begin{array}{l}2018 \\
\text { MEXICO }\end{array}$ & $\begin{array}{l}\text { Descriptive study } \\
\qquad n=328\end{array}$ & $\begin{array}{l}\text { Problem Based } \\
\text { Learning }\end{array}$ & $\begin{array}{l}\text { The Problem Based Learning encourages } \\
\text { student involvement and encourages the } \\
\text { use of prior knowledge in small group } \\
\text { environments. }\end{array}$ \\
\hline $\begin{array}{l}\text { Developing a Serious Game for Nurse } \\
\text { Education }^{(39)}\end{array}$ & $\begin{array}{l}2018 \\
\text { NORWAY }\end{array}$ & $\begin{array}{l}\text { Descriptive study } \\
n=\text { not specified }\end{array}$ & Simulation & $\begin{array}{l}\text { Allows you to practice clinical reasoning and } \\
\text { your decision-making skills in a realistic and } \\
\text { safe environment. }\end{array}$ \\
\hline $\begin{array}{l}\text { Case-based learning: What traditional } \\
\text { curricula fail to teach Lina }{ }^{(40)}\end{array}$ & $\begin{array}{c}2015 \\
\text { LEBANON }\end{array}$ & $\begin{array}{l}\text { Descriptive study } \\
\qquad \mathrm{n}=16\end{array}$ & Case study & $\begin{array}{l}\text { Helps to recognize the details of a clinical } \\
\text { situation, understand patient data, inform } \\
\text { decisions and reflect on the situation. }\end{array}$ \\
\hline $\begin{array}{l}\text { Theory and practice in the } \\
\text { construction of professional identity } \\
\text { in nursing students: A qualitative } \\
\text { study }\end{array}$ & $\begin{array}{l}2015 \\
\text { SPAIN }\end{array}$ & $\begin{array}{l}\text { Descriptive study } \\
\mathrm{n}=\text { not specified }\end{array}$ & $\begin{array}{l}\text { Problem Based } \\
\quad \text { Learning }\end{array}$ & $\begin{array}{l}\text { Helps deal with new problems, manage your } \\
\text { knowledge, take responsibility for events, make } \\
\text { decisions, reflect and develop critical thinking }\end{array}$ \\
\hline $\begin{array}{l}\text { Self-directed Learning Readiness } \\
\text { Is Independent of Teaching and } \\
\text { Learning Approach in Undergraduate } \\
\text { Nursing Education }{ }^{(42)}\end{array}$ & $\begin{array}{l}2017 \\
\text { SOUTH AFRICA }\end{array}$ & $\begin{array}{l}\text { Comparative } \\
\text { quantitative cross- } \\
\text { sectional study } \\
n=159\end{array}$ & $\begin{array}{l}\text { Problem Based } \\
\quad \text { Learning }\end{array}$ & $\begin{array}{l}\text { The overall results show that while Problem } \\
\text { Based Learning is effective in self-directed } \\
\text { learning, there is no difference between } \\
\text { Problem Based Learning and traditional learners. }\end{array}$ \\
\hline
\end{tabular}

As for the obstacles to active learning methodologies, there is a lack of preparation of the actors involved, both students and facilitators, linked to the lack of structural support, which contributes to the dissatisfaction of students.

Students are dissatisfied with the use of active learning methodologies, either because they are unaware of the method itself or because they find it difficult to express a certain criticality in certain discussions. Regarding group work, they attributed as obstacles the unpreparedness of some colleagues for the activity and their own difficulty in exposing the knowledge acquired in individual study. The inexperienced facilitators with the method end up generating a negative impact on the academic performance of the student.

As for structural support, the articles pointed to situations of inefficient structure for the contribution of the activity and disorganized logistics, making the activity ineffective, which disfavors the adhesion of students. As an example, in strategies of active learning methodologies in the virtual modalities, the students did not have technical advice for the use of the platforms, and this contributed to dissatisfaction in the activity. In the flipped classroom strategy, students pointed out difficulties in accessing the content of the class previously, a fact that disfavours the very objective of the strategy.

\section{DISCUSSION}

In the analysis of the literature on the use of active learning methodologies in undergraduate nursing courses, there are articles published in different countries and continents, which reinforce the worldwide concern to adopt teaching methods that bring the student as the center of the process and that, stimulate the active search for knowledge.

As for the level of evidence in the analyzed articles, level 4 is predominant, since reports of experiences and descriptive studies prevailed, signaling that more in-depth studies are still needed, since this is a highly relevant topic because it involves the training of professionals to act in a reality in frank process of change ${ }^{(9)}$.
In order to practice active learning in Nursing undergraduate courses, it was found in this review that different strategies are used. Among them, simulation stands out for providing the student with the possibility of approaching professional practice, making him/her more prepared for the job market, with a view to ensuring safe assistance according to society's demands $s^{(12,17-19,23,25,27,34,39)}$. Through simulation, it is possible to develop clinical reasoning, communication, self-confidence, autonomy, critical and reflective learning, creativity, interdisciplinary training and articulation of the cognitive, psychomotor and affective attributes. It is a strategy that focuses on patient safety and is linked to the improvement of clinical outcomes and effectiveness of the professional ${ }^{(43)}$.

In turn, the LFT starts from a problem situation, values the previous knowledge of students, aims to generate doubts and concerns breaking barriers between theory and practice, thus enabling more meaningful learning. The authors who cite this active learning methodology highlight its importance in the development of autonomy and clinical reasoning ${ }^{(13,22,29,38,41-42)}$.

The flipped classroom stimulates the student to research all the content before the class, optimizing the time that would be spent in the exposure made by the teacher. Thus, students go to class already prepared, with the content studied, resulting in greater enjoyment and satisfaction of learning that will occur in an interactive and cooperative manner ${ }^{(10-11,20,28)}$.

This strategy promotes a better preparation of the student for clinical practice, developing his self-confidence and communication skills. However, it requires that the facilitators of this process be properly trained and qualified so that the classroom becomes a student-centered environment, ensuring that the student is actively involved in the training process ${ }^{(10)}$.

Regarding the use of mobile phones, tablets and other technological elements, besides stimulating curiosity and critical thinking, they contribute to the fixation and understanding of content and provide instantaneous feedback, generating student satisfaction and favoring their learning ${ }^{(14,34,39)}$. In a comparative study, which involved the traditional methodology and the use 
of these technologies, the final results showed higher scores for the group submitted to active learning methodology strategies. However, students criticized the lack of interpersonal interaction that the method proposes ${ }^{(21)}$.

The case study strategy provides students with a rich experience of active learning through cases of patients based on real events in order to identify problems that occur in clinical practice ${ }^{(33,40)}$. This active methodology strategy provides students with skills such as attention capacity for patient care, initiative to learn at a distance, self-confidence, self-assessment, co-responsibility for learning and good conditions to act in a clinical situation. As with other strategies, in the case study, facilitating knowledge is the role of the educator, while developing clinical knowledge is the function of the learner, which contributes to the student's better progress ${ }^{(40)}$.

Cooperative learning, based on three theoretical structures, namely social interdependence, behavioral learning and cognitive learning theories, occurs when students work interdependently in groups to achieve shared learning objectives. This strategy teaches students to work with each other, to trust and to be receptive to each other and to the learning environment, taking into account the experience that colleagues bring ${ }^{(16)}$. In addition to the possibility of active learning, cooperative learning allows a process of self-reflection, because in collective contact, the student is able to identify his/her strengths and weaknesses within the content discussed ${ }^{(37)}$.

The problematization, in turn, is part of a real problem and is configured in a dialectic process of action-reflection-action, having as its starting point and arrival point the social reality. From this perspective, it was found that, through the active participation of the student, there is a dynamic process of knowledge construction, resolution and evaluation of problems, causing him, in the face of the problem, to resignify his discoveries, contributing to the formation of the generalist, humanist, critical and reflective nurse ${ }^{(26,29)}$.

Other strategies include Conceptual Mapping, Problematic Situations, the use of Portfolio, Imaginative Learning, Critical Thinking Cards, and Authentic Assessment Pedagogy as pathways

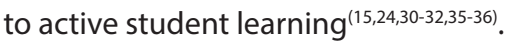

It is reinforced that, in active learning methodologies, students approach the phenomenon to be studied, engage in discussions that broaden their initial concept and then apply the knowledge to the collective ${ }^{(20)}$. In this way, they feel more prepared, satisfied, self-confident and stimulated, which has direct implications on their subsequent professional experience $\mathrm{e}^{(10,20,28)}$.

The importance of the active search for knowledge in the training of nurses was demonstrated in a study that compared the engagement of students in two groups submitted to different methodologies, and those who used active learning methodologies had better results ${ }^{(44)}$. These findings reinforce the need to stimulate the formation of a proactive student, who participates in his learning process, from triggers capable of promoting motivation and interest in conducting searches that lead to the provision of qualified care ${ }^{(44)}$.

In the studies analyzed, it is also verified that the active learning methodologies favor the integration of theory and practice, through the reflection on the experiences of professional practice, whether real or simulated, because it allows the student a process of reconstruction of the phenomenon studied and a deeper understanding of $\mathrm{it}^{(13,20,24,30,36)}$. In addition, the use of active methodologies enables students to evaluate their learning, thus promoting reflexive learning by integrating theoretical and practical knowledge ${ }^{(30)}$.

The previous experience of the practice allows the nursing students an approach with the possible cases that they may find in the different professional contexts. And this previous experience is reverted into knowledge, generating safety since, by previously practicing future situations, students will have the possibility to review their professional conduct and ability, establishing a bridge between theory and practice ${ }^{(25,27)}$.

The ability to work in groups and to communicate interpersonal are considered essential conditions for the training of nurses, since nursing is a profession practiced essentially in teams, which makes it necessary to understand the ways of dealing with communication in the group process. This capacity is especially developed through strategies such as problematization, flipped classroom, simulation and LFT ${ }^{(10,12-13,16,29,37)}$.

The development of critical thinking is put as a priority for the training of nurses and represents a great challenge, since it is given characteristics such as responsibility, security, autonomy, ability to question the experiences of reality, empathy, flexibility, respect, among other skills required for a professional of excellence. It is a complex process, which requires cognitive, mental and behavioral skills that stimulate decision making by a critical thinker, who must reason on the consequences of phenomena that need immediate intervention ${ }^{(45)}$. From this perspective, active learning methodologies break with the dichotomy between theory and practice and encourage the ability to think critically, solve problems and reflect practice, because it presents itself with great complexity ${ }^{(15,19,23)}$.

Students' difficulties with active learning methodologies occur, for example, when they do not read the content before class, thus failing to take responsibility for learning; or when the colleague in the group is unable to clearly convey the knowledge obtained from the searches made and therefore feels anguished to know whether others have been able to understand the content past or not ${ }^{(16,24)}$.

Regarding the facilitator of the teaching-learning process, it is necessary that this professional is trained to develop activities in order to optimize the time according to the final objective of the dynamics ${ }^{(20,22,24)}$. Facilitator preparation should include ways to deal with student resistance as well as setbacks that may occur during the course of the strategy ${ }^{(16)}$. Furthermore, it is important that this professional knows how to recognize the profile of his students in order to make the teaching-learning process more meaningful(35).

The facilitator plays an important role in the success or failure of the method adopted, however, since the training of this professional is derived from a traditional methodology, a continuous process of training and reflection on how to develop the learning process is necessary, which should be supported by the principles that direct the active learning methodologies ${ }^{(16,22,35)}$.

In the use of active learning methodologies, there is an indication that structural resources are not always sufficient to ensure 
a satisfactory process, and structural investments are needed to train facilitators, adjust the relationship between theory and practice, and restructure some activities ${ }^{(14,46)}$.

\section{Study limitations}

It is presented as a limitation of this study the possibility of not having exhausted all the articles published on this subject. In addition, the literature on the subject is still with a low degree of evidence, which shows the need for more in-depth studies.

\section{Contributions to the Nursing area}

The results of this study contribute to the improvement in the development of the teaching and learning process in the training of nurses and to future curricular reforms that may be adopted by the institutions, since this research reveals the advances and, essentially, the challenges to be overcome by all the actors involved in the implementation and development of active methodologies.

\section{FINAL CONSIDERATIONS}

After analyzing the articles on the use of active learning methodologies in the training of nurses, it was reported that this proposal has been used worldwide.

Regarding to active learning methodology strategies used in nurse training, simulation, LFT and flipped class strategy, virtual strategies, cooperative learning, case study and problematization are highlighted. The active learning methodology aims to put the student at the heart of the teaching learning process, favoring the development of critical thinking as well as the ability to make decisions, making him/her more autonomous and responsible for his/her own learning. However, it is evident the need for preparation of the actors involved and structural organization for these strategies to be effective.

\section{FUNDING}

This research was carried out with support from the São Paulo State Research Support Foundation (FAPESP).

\section{REFERENCES}

1. Sayyah M, Shirbandi K, Saki-Malehi A, Rahim F. Use of a problembasedlearning teaching model for undergraduate medical and nursing education: a systematic review and meta-analysis. Adv Med Educ Pract. 2017;8(1):691-700. doi: 10.2147/AMEP.S143694

2. Ministério da Educação (BR). Conselho Nacional de Educação. Câmara de Educação Superior. Resolução CNE/CES n. 3, de 7 novembro de 2001. Institui as diretrizes curriculares nacionais do curso de graduação em Enfermagem. Diário Oficial da União, Brasília (DF);9 nov 2001;Seção 1:37.

3. Winters JRF, Prado ML, Waterkemper R, Kempfer SS. Formação dialógica e participativa na Enfermagem: contribuição ao desenvolvimento do pensamento crítico-reflexivo e criativo de acadêmicos. Rev Min Enferm. 2017;21:e-1067. doi: 10.5935/1415-2762.20170077

4. Christofoletti G, Fernandes JM, Martins AS, Oliveira Jr AS, Carregaro RL, Toledo AM. Grau de satisfação discente frente à utilização de métodos ativos de aprendizagem em uma disciplina de Ética em saúde. Rev Eletrônica Educ. 2014;8(2):188-97. doi: 10.14244/19827199823

5. Espejo R. ¿Pedagogía activa o métodos activos? El caso del aprendizaje activo en la universidad. Rev Digit Investig Docencia Univ. 2016;10(1):16-27. doi: 10.19083/ridu.10.456

6. Inoue CYA, Valença MM. Contribuições do aprendizado ativo ao estudo das Relações Internacionais nas universidades brasileiras. Merid 47. 2017;18:e18008. doi: 10.20889/M47e18008

7. Souza MT, Silva MD, Carvalho R. Revisão integrativa: o que é e como fazer. Einstein [Internet]. 2010 [cited 2020 Feb 10];8(11):102-6. Available from: https://journal.einstein.br/pt-br/article/revisao-integrativa-o-que-e-e-como-fazer/

8. Lockwood C, Porritt K, Munn Z, Rittenmeyer L, Salmond S, Bjerrum M, et al. Chapter 2: Systematic reviews of qualitative evidence. In: Aromataris E MZ, editor. Joanna Briggs Institute Reviewer's Manual[Internet]. 2017 [cited 2020 Feb 10]. Available from: https:// reviewersmanual.joannabriggs.org/

9. Centre for Evidence-Based Medicine. OCEBM Levels of Evidence [Internet]. Oxford: Oxford Centre for Evidence-Based Medicine; 2016 [cited 2020 Feb 10]. Available from: https://www.cebm.net/2016/05/ocebm-levels-of-evidence/

10. Burden ML, Carlton KH, Siktberg L, Pavlechko G. Flipping the Classroom Strategies for Psychiatric-Mental Health Course. Nurse Educ. 2015;40(5):233-6. doi: 10.1097/NNE.0000000000000162

11. Costello M. The benefits of active learning: applying Brunner's Discovery Theory to the classroom: teaching clinical decision-making to senior nursing students. Teach Learn Nurs. 2017;12(3):212-3. doi: 10.1016/j.teln.2017.02.005

12. Docherty A, Warkentin P, Borgen J, Garthe KA, Fischer KL, Najjar RH. Enhancing Student Engagement: innovative strategies for intentional learning. J Prof Nurs. 2017;34(6):470-4. doi: 10.1016/j.profnurs.2018.05.001

13. Ellis KK, Anderson KM, Spencer JR. The living family tree: bridging the gap between knowledge and practice in a Family Nurse Practitioner Program. J Nurs Pract. 2015;1(5):487-92. doi: 10.1016/j.nurpra.2015.03.014

14. Gallegos C, Tesar AJ, Connor K, Martz K. The use of a game-based learning platform to engage nursing students: a descriptive, qualitative study. Nurs Educ Pract. 2017;27:101-6. doi: 10.1016/j.nepr.2017.08.019 
15. Holland C, Ulrich D. Critical thinking cards: an innovative teaching strategy to bridge classroom knowledge with clinical decision making. Teach Learn Nurs. 2016;11(3):108-12. doi: 10.1016/j.teln.2016.01.005

16. Schoening AM, Selde MS, Goodman JT, Tow JC, Selig CL, Wichman C, et al. Implementing Collaborative Learning in Prelicensure Nursing curricula student perceptions and learning outcomes. Nurs Educ. 2015;40(4):183-8. doi: 10.1097/NNE.0000000000000150

17. Staykova MP, Stewart DV, Staykov DI. Back to the Basics and Beyond: comparing traditional and innovative strategies for teaching in Nursing skills laboratories. Teach Learn Nurs. 2017;12(2):152-7. doi: 10.1016/j.teln.2016.12.001

18. Cummings CL, Connelly LK. Can nursing students' confidence levels increase with repeated simulation activities?. Nurse Educ Today. 2016;36:419-21. doi: 10.1016/j.nedt.2015.11.004

19. Moyer SM. Large Group Simulation: using combined teaching strategies to connect classroom and clinical learning. Teach Learn Nurs. 2016;11(2):67-73. doi: 10.1016/j.teln.2016.01.002

20. Dehghanzadeh S, Jafaraghaie F. Comparing the effects of traditional lecture and flipped classroom on nursing students' critical thinking disposition: a quasiexperimental study. Nurse Educ Today. 2018;71:151-6. doi: 10.1016/j.nedt.2018.09.027

21. Jafarizadeh H, Rahmani A, Habibzadeh H, Amiri S, Moghaddam AS, Moradi Y. The effect of blended training (Programmed and Lecture-Based Training) on learning health status assessment course among nursing students. Bali Med J. 2017;6(3):606-10. doi: 10.15562/bmj.v6i3.688

22. Gholamia M, Moghadam PK, Mohammadipoor F, Tarahib MJ, Sak M, Toulabia T, et al. Comparing the effects of problem-based learning and the traditional lecture method on critical thinking skills and metacognitive awareness in nursing students in a critical care nursing course. Nurse Educ Today. 2016;45:16-21. doi: 10.1016/j.nedt.2016.06.007

23. Zarifsanaiey N, Amini M, Saadat F. A comparison of educational strategies for the acquisition of nursing student's performance and critical thinking: simulation-based training vs. integrated training (simulation and critical thinking strategies). BMC Med Educ. 2016;16(1):294. doi: 10.1186/s12909-016-0812-0

24. Moraes A, Alves JB, Alves RM, Guariente MHDM. Strategies for teaching and learning in the hospital nursing school of an integrated curriculum. Rev Enferm UFPE. 2017;11(11):4289-97. doi: 10.5205/reuol.23542-49901-1-ED.1111201703

25. Costa RRO, Medeiros SM, Martins JCA, Cossi MS, Araújo MS. Percepção de estudantes da graduação em enfermagem sobre a simulação realística. Rev Cuid. 2017;8(3):1799-808. doi: 10.15649/cuidarte.v8i3.425

26. Hermida PMV, Barbosa SS, Heidemann ITSB. Metodologia ativa de ensino na formação do enfermeiro: inovação na atenção básica. Rev Enferm UFSM. 2015;5(4):683-91. doi: 10.5902/2179769216920.

27. Souza EFD, Silva AG, Silva AlLF. Active methodologies for graduation in nursing: focus on the health care of older adults. Rev Bras Enferm. 2018;71(2):920-4. doi: 10.1590/0034-7167-2017-0150

28. Park EO, Park JH. Quasi-experimental study on the effectiveness of a flipped classroom for teaching adult health nursing. Jpn J Nurs Sci. 2017;15(2):125-34. doi: 10.1111/jjns.12176

29. Kanga KA, Kimb S, Kimc SJ, Ohd J, Lee M. Comparison of knowledge, confidence in skill performance (CSP) and satisfaction in problembased learning (PBL) and simulation with PBL educational modalities in caring for children with bronchiolitis. Nurse Educ Today. 2015;35(2):315-21. doi: 10.1016/j.nedt.2014.10.006

30. Bressington DT, Wong WK, Lam KKC, Chien WT. Concept mapping to promote meaningful learning, help relate theory to practice and improve learning self-efficacy in Asian mental health nursing students: a mixed-methods pilot study. Nurse Educ Today. 2018;60:47-55. doi: 10.1016/j.nedt.2017.09.019

31. Chan ZC. Student peer reviewers' views on teaching innovations and imaginative learning. Nurse Educ Today. 2016;39:155-60. doi: 10.1016/j.nedt.2016.02.004

32. Henderson A, Harrison P, Rowe J, Edwards S, Barnes M, Henderson S, et al. Students take the lead for learning in practice: a process for building self-efficacy into undergraduate nursing education. Nurs Educ Pract. 2018;31:14-9. doi: 10.1016/j.nepr.2018.04.003

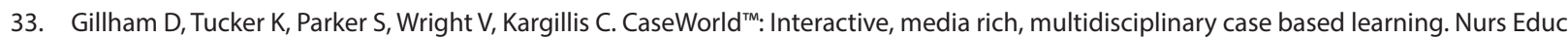
Pract. 2015;15(6):567-71. doi: 10.1016/j.nepr.2015.10.003

34. Carley A. Using technology to enhance nurse practitioner student engagement. Nurs Pract. 2015;40(7):47-54. doi: 10.1097/01. NPR.0000465119.04536.0e

35. Alharbi HA, Almutairi AF, Alhelih EM, Alshehry AS. The Learning Preferences among Nursing Students in the King Saud University in Saudi Arabia: a cross-sectional survey. Nurs Res Pract. 2017;2017:3090387. doi: 10.1155/2017/3090387

36. Chong EJ, Lim JS, Liu Y, Lau YY, Wu VX. Clinical education Improvement of learning domains of nursing students with the use of authentic assessment pedagogy in clinical practice. Nurs Educ Pract. 2016;20:125-30. doi: 10.1016/j.nepr.2016.08.002

37. Lock J, Rainsbury J, Clancy T, Rosenau P, Ferreira C. Influence of co-teaching on undergraduate student learning: a mixed-methods study in nursing. Teach Learn Inq. 2018;6(1):38-51. doi: 10.20343/teachlearninqu.6.1.5

38. Ding Y, Zhang P. Practice and effectiveness of web-based problem-based learning approach in a large class-size system: a comparative study. Nurs Educ Pract. 2018;31:161-4. doi: 10.1016/j.nepr.2018.06.009

39. Johnsen HM, Fossum M, Vivekananda-Schmidt P, Fruhling A, Slettebø Å. Developing a Serious Game for Nurse Education. J Gerontol Nurs. 2018;44(1):15-9. doi: 10.3928/00989134-20171213-05 
40. Kantar LD, Massouh A. Case-based learning: what traditional curricula fail to teach. Nurse Educ Today. 2015;35(8):e8-14. doi: 10.1016/j. nedt.2015.03.010

41. Arreciado Marañóna A, Isla Perab MP. Theory and practice in the construction of professional identity in nursing students: a qualitative study. Nurse Educ Today. 2015;35(7):859-63. doi: 10.1016/j.nedt.2015.03.014

42. Qamata-Mtshali N, Bruce JC. Self-directed learning readiness is independent of teaching and learning approach in undergraduate nursing education. Nurse Educ. 2017;43(5):277-81. doi: 10.1097/NNE.0000000000000493

43. Paige JT, Terry Fairbanks RJ, Gaba DM. Priorities related to improving healthcare safety through simulation. Simul Healthc. 2018;3(3S Suppl 1):S41-S50. doi:10.1097/sih.0000000000000295

44. Escrivão Filho E, Ribeiro LRC. Aprendendo com PBL: aprendizagem baseada em problemas: relato de uma experiência em cursos de engenharia da EESC-USP [Internet]. Minerva. 2009 [cited 2020 Feb 10];6(1):23-30. Available from: http://www.fipai.org.br/Minerva\%20 06(01)\%2003.pdf

45. Dias JAA, David HMSL, Rodrigues BMRD, Peres PLP, Pacheco STA, Oliveira MS. A moral e o pensamento crítico: competências essenciais à formação do enfermeiro. Rev Enferm UERJ. 2017;25:e26391. doi: 10.12957/reuerj.2017.26391

46. Higa EFR, Moreira HM, Pinheiro OL, Tonhom SFR, Carvalho MHR, Braccialli LAD. Caminhos da avaliação da aprendizagem ativa: visão do estudante de medicina. Rev Lusófona Educ. 2018;40(40):171-84. doi: 10.24140/issn.1645-7250.rle40.03 